\title{
Elokuva psykologisena ilmiönä: Münsterberg, Eisenstein ja kognitiopsykologia
}

\begin{abstract}
Kognitiopsykologia on viime vuosina noussut keskeisen teoreettisen viitekehyksen asemaan elokuvatutkimuksen parissa. Empiiriseen psykologiseen tutkimukseen ja teoretisointiin nojaava lähestymistapa on kuitenkin kuulunut elokuvateoreettisiin pohdintoihin jo vuosisadan alusta saakka. Tarkastelen seuraavassa aluksi Hugo Münsterbergin (1863-1916) ja Sergei Eisensteinin (1898-1948) keskeisiä olettamuksia katsomiskokemuksesta ja katsojan mentaalisista prosesseista. Kåsittelen ensinnäkin Münsterbergin ja Eisensteinin katsojateorioita ja psykologisia kăsityksiă ja osoitan niiden läheisen sukulaisuuden. Seuraavaksi pyrin hahmottamaan heidăn empiirisestă psykologiasta ponnistavien näkemystensă suhdetta modernin kognitiopsykologisen elokuvatutkimuksen teoreettisiin olettamuksiin. Varsinaisena päämääränäni on osoittaa kokeellisen psykologian pitkä aate- ja tieteenhistoriallinen vaikutus elokuvateoriaan ja käsityksiin katsojan psykologisista toiminnnoista. Tarkasteluni rajautuu koskemaan empiiriseen tutkimukseen perustuvaa kokeellisen psykologian traditiota, ts. rajaan psykoanalyysiin perustuvat kăsitykset elokuvakokemuksesta tămăn tarkastelun ulkopuolelle.
\end{abstract}

\section{Mielen vangitseva viihde}

Jo lyhyen historiansa alkuajoista lăhtien elokuva on herăttănyt runsaasti mielenkiintoa ilmaisullisena vălineenä ja taidemuotona, jolla on koettu olevan erityisen voimakas vaikutus katsojiinsa. Aluksi katsojien huomion riitti kiinnittämään elokuvan tekninen ominaislaatu, joka mahdollisti kohteen mekanisen reprodusoinnin valkokankaalle. Erityisesti liikkeen luonnollinen ilmaiseminen korosti elokuvan todenkaltaisuutta ja piti pitkään yllä elokuvan attraktioarvoa markkinayleisön joukossa. Varsin pian kuitenkin havaittiin myös elävien kuvien esittävä funktio ja sen myötä myös yhteiskunnallisten vaikutusten mahdollisuus. Keskustelu elokuvien sisällön moraalittomuudesta 
I. Ks. esim. Eileen Bowser, The History of American Cinema, Vol 2 The Transformation of Cinema 1907-1915. Berkeley: University of California Press 1990. 37-72.

2. Sabina Hake, The Cinema's 3rd Mochine. Writing on Film in Germany 1907-33. Lincoln and London: University of Nebraska Press 1993, 10.

\section{Varhaisen} elokuvajournalismin historiasta Saksassa ks. Hake 1993, 3-104 ja USA:ssa Myron Lounsbury, The Origins of Americon Film Criticism 1909-1939. New York: Arno Press 1973.

4. Hugo Münsterberg. "Why We Go the "Movies"'. Cosmopolitan vol. LX:I (Dec. 1915), 31; Hugo Münsterberg. The Film. A Psychologial Study. New York: Dover 1970, 17. The film on Photoplay teoksen uudelleenjulkaisu. Suomennokset tässä ja jatkossa tekijän.

5. Jaottelusta klassiseen ja moderniin elokuvateoriaan ks. Noël Carroll. Philosophical Problems in Classical Film Theory. New Jersey: Princenton UP 1988. 10.15. ja haitallisuudesta käynnistyi 1910-luvulla kerrontaelokuvan kehittymisen myőtä ja laajojen kansanjoukkojen ahtautuessa hämäriin elokuvateattereihin. Seurauksena oli alaa kontrolloimaan pyrkivien sensuurijärjestelmien văhittăinen tulo lähes kaikkiin maihin, joissa elokuvia ylipäätään tuotettiin ja esitettiin. ' Varhainen sensuuri esimerkiksi Saksassa ei kuitenkaan arvioinut elokuvien haitallisuutta niinkään sisällön perusteella, vaan kriteerinä käytettiin niiden vaikuttavuutta yleisöön, jolloin keskeiseksi arviointiperustaksi nousivat yleisőn emotionaaliset reaktiot. ${ }^{2}$

Varhaisessa elokuvaa käsittelevässä kirjoittelussa - harvat elokuvaan erikoistuneet lehdet ja yksittäiset artikkelit erilaisissa julkaisuissa-keskeinen huomio kohdistui elokuvaan păäasiallisesti teknisenä, taloudellisena ja yhteiskunnallisena ilmiönä sekä luonnollisesti myös massaviihteenä. ${ }^{3}$ Elokuvan suosio herătti kuitenkin pian myös teoreettisen kiinnostuksen elokuvaan, joka koettiin vähitellen ajatuksia ja tunteita herättävänä uutena taiteenmuotona, modernina 'seitsemăntenă taiteenlajina'. Elokuvan ilmeisen voimakkaat psykologiset vaikutukset katsojissa innoittivat tarkastelemaan lähemmin elokuvan ja katsojan vălistă suhdetta. Vastasyntyneen Neuvostoliiton elokuvantekijāteoreetikkojen montaasikokeilut ja elokuvan propagandististen mahdollisuuksien tutkiminen ovat katsojalähtöisen elokuvaoreettisen lähestymistavan selkeimpiă esimerkkejă.

Systemaattisin klassisen elokuvateorian elokuvakokemukseen ja elokuvan katsomiseen liittyviin psykologisiin prosesseihin keskittyvä analyysi on kuitenkin löydettăvissă jo lăhes vuosikymmen aikaisemmin Hugo Münsterbergin teoksesta Photoplay. A Psychological Study (1916) sekä hänen elokuvaa kăsittelevistả artikkeleistaan. Saksalaissyntyisellä Münsterbergillä oli oivalliset valmiudet kăsitellă nuorta taiteenlajia juuri psykologian năkőkulmasta. 1800-luvun lopulta saakka Harvardin yliopiston kokeellisen psykologian professorina vaikuttanut Münsterberg noteerattiin aikansa kokeellisen ja soveltavan psykologiatutkimuksen eturintamaan. Optimistisesti hän julisti vuonna 1915 elokuvan taiteeksi, joka "tulisi enemmän kuin mikăăn muu taiteenlaji mielen toimintaa analysoivan psykologin alueeksi". Ennen kaikkea tarvittiin tutkimusta "niistä keinoista, joilla elokuvat vaikuttavat ja vetoavat meihin".

Münsterbergin toivoma psykologinen lähestymistapa elokuvatutkimukseen ei kuitenkaan saanut juurikaan vălittőmiă seuraajia. Hănen teoksensa unohdettiin pikaisesti julkaisemisensa jälkeen ja elokuvateoria suuntautui enemmän elokuvan formaalien ilmaisukeinojen tutkimiseen kuin varsinaiseen katsojapsykologiaan. Poikkeuksena ovat mainitut neuvostoteoreetikot, erityisesti Sergei Eisenstein, jonka elokuvan ilmaisukeinojen tarkastelun lähtökohtana oli pyrkimys katsojan mentaalisten prosessien kontrollointiin. Esteettinen tutkimussuuntaus hallitsi elokuvateoreettista kirjoittelua aina 1960luvulle asti, niin sanotun modernin elokuvateorian syntyyn saakka, ${ }^{5}$ jolloin katsoja nousi jälleen keskeisen huomion kohteeksi. Semiotiikaan, marxilaiseen ideologiateoriaan ja psykoanalyysiin nojaava elokuvateoreettinen lähestymistapa poikkesi kuitenkin ratkaisevasti Münsterbergin (ja myös Eisensteinin) katsoja psykologisista näkemyksistä. Psykoanalyysin vaikutuksesta psykosemioottinen elokuvateoria kiinnitti huomionsa katsojan alitajuisiin prosesseihin ja oletti hänet psykologisesti epäyhtenäiseksi, passiiviseksi ja konstruoiduksi entiteetiksi, joka asemoidaan erilaisin elokuvallisin keinoin ideologisille vaikutuksille alttiiksi subjektiksi. Katsojan emotionaalinen eläytyminen oli ensimmäinen askel ideologisen värväyksen tiellä. 


\section{Suuret Teoriat ja kognitivistinen käänne}

Münsterbergin nimi tuli uudestaan ajankohtaiseksi elokuvateorian 'kognitivistisen käänteen' myötä 1980-luvulla. Alkujaan lähinnä Wisconsinin yliopiston tutkijoihin (David Bordwell, Noël Carroll ja Kirstin Thompson) liitetty neoformalismiksi ja historialliseksi poetiikaksi nimetty suuntaus kyseenalaisti voimakkaasti psykosemioottisen elokuvateorian mielekkyyden. Bordwellin keskeisten vaikuttajahamojen mukaan SLAB - teoriaksi (Ferdinand de Saussure, Jacques Lacan, Louis Althusser ja Roland Barthes) nimeämää psykosemioottista teoriaa kritisoitiin ennen kaikkea teoreettisia väittämiă tukevan empiirisen aineiston ja tutkimuksen puutteesta sekä keskittymisestä katsojan irrationaalisiin, tiedostamattomiin, mentaalisiin toimintoihin. ${ }^{6}$

Bordwell ja Carroll ovat kutsuneet 1970-luvun varsin erilaisista lähtökohdista ponnistavia lähestymistapoja elokuvatutkimukseen myös 'Suuriksi Teorioiksi' tai yksinkertaisesti Teoriaksi, sillä ne tarkastelevat kohdettaan teorialähtöisesti, sofistikoituneiden teoreettisten konstruktioiden avulla. Edelleen ne pyrkivăt elokuvan avulla kuvaamaan tai selittämään varsin laajoja alueita yhteiskunnasta, historiasta, kielestä ja ihmisen psyykestä. Suurten Teorioiden tilalle Bordwell ja Carroll ovat tarjonneet pragmaattisempia lăhtőkohtia, metodologista pluralismia ja ongelmakohtaista lähestymistapaa. Suurten Teorioiden sijaan elokuvatutkimus onkin viime aikoina suuntautunut osateorioihin esimerkiksi kerronnasta (Bordwell, Narration in the Fiction Film; Edward Branigan, Narrative Comprehension and Film), lajityypeistä (Carroll, Philosophy of Horror) ja tunteista (Murray Smith, Engaging Characters). Samalla psykoanalyyttinen lähestymistapa katsojuuteen on korvautunut kognitiopsykologiasta peräisin olevilla teoreettisilla viitekehyksillă ja kokeellisen tutkimuksen välittämällä empiirisellä aineistolla.

Münsterbergin nimi on noussut uudestaan esille juuri kognitiopsykologisten näkemysten yhteydessä. Münsterbergiin on viitattu taajaan kognitivistien artikkeleissa ja teoksissa aina 1980-luvulta lähtien. Lähinnä häneen vedotaan varhaisena metodologisena edeltăjänă, joka niin ikăăn sovelsi aikansa tieteellisen tutkimuksen - kokeellisen psykologian - tuloksia ja lähestymistapaa elokuvatutkimukseen:

\footnotetext{
...hăn [Münsterberg] osoitti, ettă empiirinen tutkimus voi valaista tietămystămme elokuvasta...Elokuvateorialla oli onni saada perustajakseen yksi aikansa nerokkaimmista ja koulutetuimmista ihmisistä. Erityisesti hyvăă onnea oli sïină, ettă yksi niistă harvoista ihmisistă, joka oli kykenevă analysoimaan elokuvan ja katsojan mielen vālistā suhdetta, päătti tehdā niin.s
}

\section{Münsterberg ja elokuvakokemuksen tasot}

Münsterberg kuvaa katsojateoriassaan kokonaisvaltaisen elokuvakokemuksen koostuvan neljästă, keskenăăn hierarkkisessa suhteessa olevasta psykologisesta tekijästä: liikkeen ja syvyyden havaitsemisesta, huomiokyvyn (Aufmerksamkeit, attention) toiminnasta, muistista sekă tunteista. Psykologian kannalta jo perustava elokuvakokemus on mielenkiintoisen paradoksaa-

\author{
6. Yleisesityksenă \\ "koginitiivisen kăănteen" \\ luonteesta ja \\ implikaatioista ks. Matti \\ Lukkarila "Suuret \\ teoriat, elokuvakulttuuri \\ a neoformalismin \\ haaste". Lohikuva I/ \\ 1993. \\ 7. Ks. David Bordwell. \\ "Contemporary Film \\ Studies and the \\ Vicissitudes of Grand \\ Theory" (vars. s. 18-21) \\ ja Noèl Carroll, \\ "Prospects for Film \\ Theory: A Personal \\ Assessment". Teoksessa \\ Bordwell \& Carroll \\ (eds.), Post-Theory. \\ Reconstructing Film \\ Studies. Madison, \\ Wisconsin: University \\ of Wisconsin Press \\ 1996. \\ 8. Joseph Anderson, The \\ Reality of Illision: An \\ Ecological Approach to \\ Cognitive Film Theory, \\ Chapter I: Introduction \\ [online]. Saatavilla \\ mww-muodossa: <http:/ \\ /www.mailbase.ac.uk/ \\ lists/film-philosophy/ \\ files/ \\ paper.anderson.huml>. \\ Ks. lisäksi Anderson \& \\ Anderson, "The Case \\ for an Ecological Film \\ Theory". Teoksessa \\ Bordwell \& Carroll \\ (eds.) 1996, 348.
}


9. Münsterberg 1970 , 30.

10. Münsterberg 1970 , 30.

II. Ibid., 38-9.

12. Ibid., 4I, 46.

13. Ibid., 44-5.

14. Ibid., 48.

15. Münsterberg 1915, 30. linen ilmiö, todellisuudessa liikkumaton ja lattea kuva nåyttăytyy subjektiivisessa kokemuksessamme liikkeessä ja kolmiulotteisena. Koska liike ja 'plastisuus' eivăt kuulu varsinaisesti elokuvan materiaaliseen ilmenemismuotoon tăytyy niiden hahmottamisen Münsterbergin mukaan syntyă katsojan psykologisten prosessien tuloksena: "luomme syvyyden ja jatkuvuuden mentaalisen mekanismimme avulla".

Liikkeen ja syvyyden havaitsemisen lisăksi ymmărrămme năkemiimme valoihin ja varjoihin liittyvăn myös erilaisia merkityksiä. Münsterberg vertaa merkityksen muodostumista elokuvassa vieraan kielen oppimiseen, jossa văhitellen opimme lisăämään assosiaatioita ja reaktioita kuulemiimme ăănteisiin. Visuaalisten ärsykkeiden suhteen toimimme samalla tavalla. Keskeisin merkityksenmuodostamiseen liittyvă psykologinen toiminto on aistiărsykkeită valikoiva ja suodattava huomiokyky. Myös elokuvassa katsoja valitsee sen avulla jatkuvasta kuvallisten årsykkeiden kaaoksesta merkitykselliset ja tarkoituksenmukaiset ainekset. Valinta tapahtuu joko katsojan omien intressien ohjaamana tai elokuvantekijöiden asettamien suuntaviivojen mukaisesti.

Huomion kohdistuminen johonkin objektiin käynnistăă sarjan fyysisiă ja psykologisia prosesseja, jotka pyrkivăt syventämăăn tietoamme kohteesta ja sen merkityksestả. Esimerkiksi lukiessaamme kirjaa huomiomme kohdistuu korostetusti teokseen ja muiden ärsykkeiden merkitys (huoneet muut esineet, åănet jne.) mielessămme văhenee. Pyrimme myös fyysisesti keskittämăăn huomiomme kohteeseen, suuntamme katseemme, vaihdamme mahdollisesti asentoa ja jännitämme ruumiimme lihaksistoa. Kokonaisuudessaan "ajatuksemme, tunteemme ja impulssimme ryhmittyvăt kohteena olevan objektin ympärille". ${ }^{10}$ Münsterberg ei rajoita huomion kohdistamista pelkåstăån elokuvan kerronnan kannalta olennaisiin elementteihin, vaan ulottaa sen myös kerronnallista toimintaa elăvőittăviin aspekteihin, kuten ilmeisiin rakastavaisten kasvoilla."

Huomiokyvyn avulla katsoja orientoituu elokuvalliseen tilaan ja sen välittämään informaatioon, muisti sen sijaan ohjaa temporaalisen mielikuvan luomista elokuvasta. Lisäksi muisti on varsinainen lähde, josta assosiaation avulla ammennamme merkityksiå huomiokyvyn suodattamille näköhavainnoillemme. Visuaalinen aistimus on vihje, joka kirvoittaa assosiaation săăntelemiå, omaan kokemukseemme tai elokuvan aiempiin tapahtumiin perustuvia muistumia ja ajatuksia. Vastaavalla tavalla kumpuavat myős mahdolliset odotukset elokuvan tulevista tapahtumista sekä tunteiden ohjaamat kuvitelmat (imagination). ${ }^{12}$

Temporaaliseen hahmottamiseen kuuluu myös samanaikaisuuden kokemus, jolloin huomio jakautuu samanaikaisesti useaan eri kohteeseen. Elokuvassa ajallisen samanaikaisuuden tuntu saadaan aikaan paralleelileikkauksen avulla. Otokset pikakirjoittajansa kanssa juhlivasta johtajasta, häntä vihaisena kotiin odottavasta vaimosta ja tytŏn huolestuneesta ăidistă kuvastavat paitsi samanaikaisuutta ja erityyppisiä kerronnallisia tilanteita, myős vastakkaisiksi koettuja tunnetiloja. Münsterbergin mukaan leikkauksen avulla manipuloitu elokuvallinen aika tuottaa parhaimmillaan monimerkityksisyyttä, joka vastaa todellisen kokemuksen rikkautta. Elokuva tuottaa katsojalle erityistă mielihyvää, sillä se antaa mahdollisuuden mentaalisten kykyjen täysipainoiseen kăyttöön. ${ }^{13}$

Elokuva on kuitenkin Münsterbergille ennen kaikkea tunteiden aluetta: "tunteiden kuvaamisen täytyy olla elokuvan päätarkoitus... elokuvan henkilöt ovat meille ennen kaikkea emotionaalisten kokemusten kokijoita". ${ }^{14}$ Müns- 
terberg pitäă tunteita ylipäătăän ihmisen mentaalisen rakenteen merkittävimpănă osana; "ihmisen ydin on hănen tunteissaan ja emootioissaan". 1s Elokuvakokemuksen olennaisena osana on voimakas emotionaalinen samastuminen elokuvan henkilöihin ja heidăn kokemuksiinsa. Năkemămme tunnetilat jopa aiheuttavat katsojassa vastaavia fyysisiă reaktioita, kauhu saa meidät käpertymään ja onni rentoutumaan. Näyttelijöiden ohella emotionaalista samastumista edesauttavat myös lavasteet, kameran liike ja leikkausrytmi.

Toisaalta katsoja reagoi elokuvaan myös oman tunne-elămănsă pohjalta, jolloin koetut emootiot voivat olla tăysin vastakkaisia valkokankaalla esitetyille. Katsoja voi esimerkiksi nähdä iloisen marjastavan lapsen ja samastua osittain hänen onneensa, mutta samalla tuntea kauhua nähdessä lapsen etenevăn kohti kallionkielekettă. Münsterberg pităă tärkeănă năiden 'lisăttyjen' emootioiden hyödyntämistä, kuitenkin pääosa katsojan kokemista tunteista on nåyttelijöiden esittämien tunteiden imitaatiota. ${ }^{16}$

Münsterberg jakaa siten elokuvakokemuksen havaintoon, sen merkityksellistämiseen huomiokyvyn ja muistin avulla sekă emootioihin korostaen kaikilla tasoilla katsojan psykologisten mekanismien aktiviteettia. Hănen mielestään elokuvakokemus on hierarkkinen prosessi, jossa tunteet ovat korkeimmalla sijalla: elokuvan keskeisin tehtăvă on sen emotionaalinen vaikuttavuus. Merkittävăä lisăksi on, että Münsterberg ei pidä elokuvakokemusta tăysin mentaalisena tapahtumana, vaan psykologian năkőkulmasta myős katsojan fyysisillă reaktioilla näyttăä olevan keskeinen osuus emootioiden ja merkitysten muodostumisessa.

Katsojan psykologiset prosessit mahdollistavat katsojan aktiivisen roolin elokuvan merkityksellistäjänä, mutta toisaalta samat prosessit antavat myös elokuvantekijöille mahdollisuuden kontrolloida ja ohjata katsomiskokemusta. Muun muassa huomion kohdentumista voidaan ohjata erilaisten visuaalisten vihjeiden (esim. lähikuva) avulla, katsojan ajatuksen juoksu voidaan suorastaan pakottaa haluttuun suuntaan hyödyntämällä hänen suggestiivisia taipumuksiaan. ${ }^{17}$ Münsterberg pităă psykologisten prosessien ohjailua hyväksyttävänä, jopa suositeltavana. Esimerkiksi huomiokyvyn yhteydessä hăn mainitsee kuinka katsojan on vain "hyvăksyttăvă ohjaajan ja kăsikirjoittajan hänelle suunnittelemat huomiokykyä ohjaavat vihjeet” ja siirrettävä huomiokykyăăn niiden mukaisesti. Münsterberg painottaa myös katsojan emotionaalisen samastumisen merkitystä, jolloin elokuvantekijät ja henkilöhahmot ohjaavat ja kontrolloivat myös katsojan tunteita. ${ }^{18}$

Münsterbergin analysoiman katsomiskokemuksen keskeiset elementit kokemuksen hierarkkisuus, assosiatiivisten prosessien, emootioiden ja fyysisten reaktioiden merkitys sekä pyrkimys mentaalisten prosessien ohjaamiseen - ovat lăsnă myös Sergei Eisensteinin näkemyksessä katsojasta, vaikkakin eri syistä ja eri tavoin painotettuna. ${ }^{19}$

\section{Eisenstein ja emootioiden järkeistämä katsoja}

Eisensteinin elokuvateorian ja varsinkin hänen katsojaa koskevien käsitystensă on tulkittu jakautuvan karkeasti kahteen erilliseen kauteen. ${ }^{20} 1920$ luvulla Eisensteinin katsojateoria perustui mm. Ivan Pavlovin (1849-1936) reaktiopsykologian vaikutuksesta varsin mekanistiselle näkemykselle elokuvan ilmaisukeinojen ja katsojan psykologisten prosessien vălisestă
16. Münsterberg 1970 ,

51, 53-6.

17. Ibid., 38-9, 46-7.

18. Ibid., 53, lainaus 33.

19. Kokeellisen psykologian ohella Münsterbergin käsitykseen katsomiskokemuksesta vaikutti hänen uuskantilainen filosofiansa. Eisenstein puolestaan tarkasteli katsojuutta kommunistisen ideologian näkökulmasta.

Münsterbergin uuskantilaisuuden suhdetta hänen elokuvateoriaansa olen käsitellyt lähemmin pro gradussani Hugo Münsterberg - psykologi elokuvateoreetikkona, Oulun yliopisto 1997.

20. Katso David

Bordwell, "Eisenstein's Epistemological Shift". Screen, vol. 15:4 (1974/ 5) sekä David Bordwell, The Cinema of Eisenstein. Cambridge, Mass: Harvard UP 1993, III138, 163-198. 
21. Sergei Eisenstein, "Perspectives" (1929). Teoksessa Eisenstein. Selected Writings 1922 34, toim. ja käănt. Richard Taylor. London: BFI Publishing 1988, 155. Bordwell 1974/5, 33, 45 .

22. Eisenstein, "Beyond the Shot". (1929). Teoksessa Eisenstein 1988, 145; Eisenstein, "The Dramaturgy of Film Form" (1929) Ibid., 166.

23. Ks. lahemmin Bordwell 1993, 169. 177-9, 195-6.

24. Eisenstein, "The Problem of the Materialist Approach to Form" (1925). Teoksessa Eisenstein 1988, 62. Kursivointi Eisensteinin.

25. Eisenstein, "The Montage of Attractions" (1923). Ibid., 34. Kursivointi Eisensteinin. suhteesta. Varhaista năkemystă voidaan pităă 'konstruktivistisena' viitaten yhtăltă elokuvan tekemiseen huolellisena yksityiskohtien koostamisena ja toisaalta năkemykseen elokuvakokemuksen muokattavuudesta. Eisensteinin mukaan katsojaan vaikuttaminen on mahdollista kokemuksen kaikilla tasoilla, myős "kognitio on konstruktiota". ${ }^{21}$

30-lukua lähestyttảesså Eisensteinin näkökulma kuitenkin muuttui hienosyisemmäksi Freudin psykoanalyysin, James Joycen Odysseuksen, Lev Vygotskin kielitieteellisten tutkimusten ja Jean Piaget'n syvyyspsykologisten năkemysten myőtä. Eisenstein kuvasi montaasia muun muassa polttomoottorina, jossa toisiaan seuraavat räjähdykset/emotionaaliset impulssit kuljettavat autoa/elokuvaa eteenpăin. Vuonna 1929 polttomoottorin rinnalle nousi vertaus elävăăn organismiin, esimerkiksi otos ymmărretäăn montaasin soluna tai molekyylină. ${ }^{22}$ Eisenstein myöhempăă teoretisointia voidaankin laajassa mielessă nimittăă 'organistiseksi', jolloin keskeisellă sijalla ovat elokuvan polyfonisuus, harmonia ja pyrkimys synteesiin usealla taholla: katsojan ajattelun ja elokuvan sekä elokuvan ja muiden taidemuotojen välillä.. ${ }^{23}$

Eisenstein ei kirjoittanut eritellysti katsojan psykologisista prosesseista Münsterbergin tavoin, mutta elokuvakokemus jakautui myös hänellä karkeasti kolmeen osaan, perustaviin havaintoihin sekã niiden emotionaalisiin ja kognitiivisiin vaikutuksiin katsojassa. Münsterbergistä poiketen hăn ei kuitenkaan kiinnittänyt juurikaan huomiota havaintoprosessiin psykologisena ongelmana. $\mathrm{Se}$, miten havaitsemme, on selkeăsti sekundaarinen kysymys verrattuna siihen, mitä valkokankaalla esitetään ja kuinka se vaikuttaa katsojaan. Keskeisimmăllă sijalla ovat katsojan varsinaista havaintoa ohjaavat tekijăt (mm. otosten välinen ja -sisäinen montaasi, ekspressiivinen näyttelijätyö, toistuvat kuvamotiivit) sekä niiden emotionaaliset ja kognitiiviset vaikutukset katsojassa. Eisensteinin năkemystă elokuvan ja katsojan yksipuolisesta vaikutussuhteesta kuvastaa hänen raju määritelmänsä vuodelta 1925: "Käsityksemme mukaan taide...on käsitettävä ennen kaikkea traktorina, joka kyntäa yleisön psyykettä määrätyssä luokkakontekstissa" ${ }^{24}$ Eisensteinin vaatimuksen taustalla on selkeä olettamus katsojan psykologisista prosesseista ja siten myös elokuvakokemuksen luonteesta. Keskeiset mentaaliset prosessit ovat Eisensteinin konstruktivistisen näkemyksen mukaan refleksien kaltaisia fysiologisia toimintoja, joista perustavin merkitys elokuvan kannalta on katsojan emootioilla.

Emootiot olivat herättäneet Eisensteinin mielenkiinnon jo hänen toimiessaan 1920-luvun alussa proletkult-teatterissa ja kirjallisuuslehti Lefin ympärille kerăäntyneiden intellektuellien parissa. Eisensteinin varhainen artikkeli 'Attraktioiden montaasi' (1923) käsitteli attraktioiksi nimettyjen emotionaalisten shokkien merkitystă teatteriyleisőlle. Tuolloin hăn mäăritteli attraktion olevan

mikă tahansa aggressiivinen hetki teatterissa, joka alistaa katsojan emotionaaliselle tai psykologiselle vaikutukselle...Nämă [emotionaaliset] shokit antavat [katsojalle] ainoar mahdollisuuden havaita esitettyyn sisaltyvă ideologinen aspekti, lopullinen ideologineı păătelmă. ${ }^{2 s}$

Vuotta myőhemmin hăn laajensi attraktion periaatteen koskemaan myös elokuvailmaisua ja ulotti sen koskemaan tunteiden ohella myös katsojan huomiokyvyn ohjaamista: 
huomiokykyyn ja tunteisiin...ja lisaksi sen on pystyttävã suuntaamaan katsojan emootiot tuotannon kulloinkin sanelemaan suuntaan. ${ }^{26}$

Attraktioilla voidaan Eisensteinin kåyttămăssă merkityksessä erottaa kahdenlaisia funktioita. Toisaalta ne kiinnittåvăt katsojan huomion valkokankaan tapahtumiin, vangitsevat hănen aistinsa saaden aikaan jopa fyysisiä reaktioita. Lisäksi attraktiot käynnistăvăt katsojassa assosiaatioiden ketjun, joka tuottaa yksittäisiă ja montaasin avulla myös kumuloituvia tunnevaikutelmia. Vaikuttavimpana esimerkkină Eisenstein käyttäă Lakko-elokuvan (Stachka, Neuvostoliitto 1924) teurastuskohtausta, jossa härkien teurastuksen
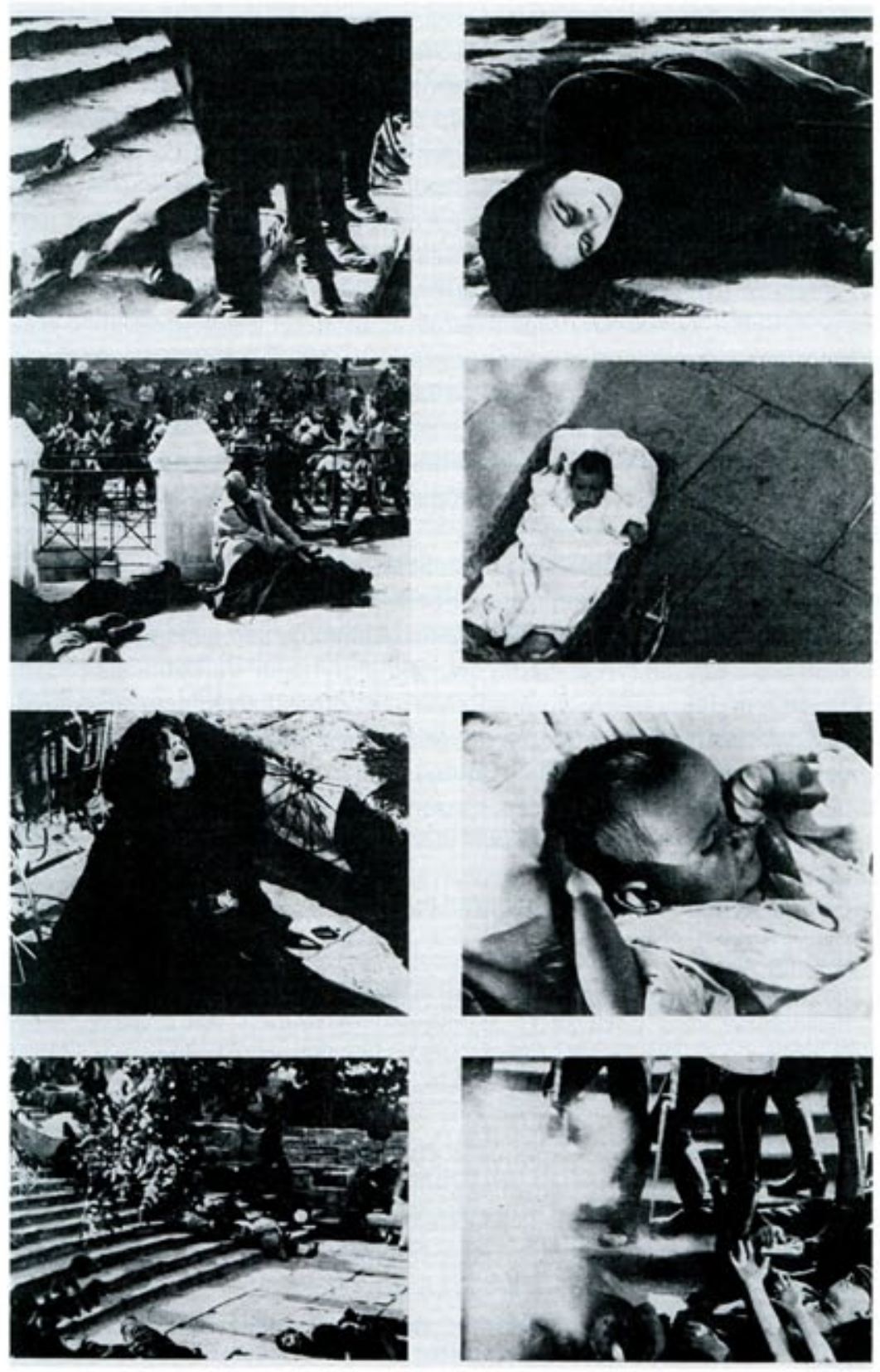

26. Eisenstein, "The Montage of Film Attractions" (1924). Ibid., 40-1.

27. Ibid., 43-4.
Eisenstein:

Panssarilaiva

Potemkin (1925)

- Odessan portaat. 
28. Marie Seaton, Eisenstein. A Biogrophy. London: The Bodley Head 1952, 78. Lainaus Eisensteinin The Notion-lehdelle antamasta haastattelusta 1927.

29. Eisenstein viittaa itse Pavloviin keskeisenä innoittajanaan em. haastattelussa, Ibid., 78 Pavlovin lisäksi toisella aikakauden keskeisellä neuvostofysiologilla, Vladimir Bekhterevillä oli keskeinen merkitys Eisensteinin ajattelulle. Bordwell 1993, 116. Ks. myös Bordwell 1974/5, 33.

30. Eisenstein, "The Montage of Film Attractions" (1924). teoksessa Eisenstein 1988, 48, 50-56.

31. Bordwell 1993, 123-5.

32. Eisenstein, "The Principles of the New Russian Cinema" (1930). Teoksessa Eisenstein 1988, 199.

33. Eisenstein, "The Fourth Dimension in Cinema" (1929). Ibid., 193. Eisenstein havainnollistaa metrisen montaasin vaikutuksia Vonhoa jo uutto-elokuvan (Staroje i novoje, Neuvostoliitto 1929) niittokohtauksella, jonka aikana osa katsojista huojuu edestakaisin niiton ja leikkauksen tahdissa. Ibid., 192. raakuus rinnastetaan montaasin avulla työläisten ampumiseen. Päămääränă on "maksimaalisen kauhun" herăttăminen katsojassa. ${ }^{27}$ Vastaava emotionaalinen kliimaksi on erotettavissa myös Panssarilaiva Potemkinin (Bronenosets Potemkin, Neuvostoliitto 1925) Odessan portaat -kohtauksesta, jossa sotilaiden jalkojen, portaiden, veren ja ihmisten muodostamia elementtejă yhdistämällä vălittyy katsojalle hyvin voimakas, jopa fyysinen tunnevaikutelma: "kun sotilaan saappaat astuvat eteenpäin hän [katsoja] kavahtaa fyysisesti. Hän pyrkii pakenemaan luodinkantaman ulkopuolelle"28.

Eisensteinin attraktioteorian hyvin mekanistinen kåsitys elokuvakokemuksesta ja katsojan psykologisista toiminnoista pohjautuu suurelta osin Ivan Pavlovin refleksien toimintaa kăsitteleviin tutkimuksiin, joiden mukaan kăyttăytyminen on redusoitavissa synnynnăisiksi tai hankituiksi refleksitoiminnoiksi. ${ }^{29}$ Vastaavasti Eisensteinin 'konstruktivistisen kauden' năkemyksen mukaan kaikki elokuvakokemuksen osatekijät ovat palautettavissa fysiologisiin reaktioihin ja myös kontrolloitavissa tăltă tasolta. Näin ollen myös emootiot ja assosiaatiot ovat Eisensteinille perustaltaan fysiologisia refleksejä, joita voidaan helposti vahvistaa tai muuntaa sopivanlaisten ärsykkeiden avulla. Keskeistä Eisensteinin ajattelussa on juuri fysiologinen momentti, olettamus emootioiden ja assosiaatioiden perustumisesta ruumiillisiin reaktioihin.Visuaaliset ärsykkeet herättävăt fyysisiă reaktioita - kuten Lakon ja Panssarilaiva Potemkinin esimerkeissä -, jotka puolestaan tuottavat emotionaalisia tuntemuksia. Katsojien emootioiden konstruoinnissa Eisenstein pităă tărkeănă myös näyttelijătyön merkitystä, sillä "katsoja saavuttaa emotionaalisen aistimuksen [emotional perception] năyttelijăn liikkeiden motorisen reproduktion kautta" ${ }^{30}$. Katsojan kokemien tunteiden keskeisenä lähteenă on siten Münsterbergin tapaan elokuvassa năhtyjen tunnetilojen imitointi.

1920-luvun loppupuolella Eisenstein tarkensi năkemystăăn katsomiskokemuksesta ja keskitti huomionsa kăsitteiden muodostukseen ja 'intellektuaalisiin' prosesseihin yleensä. Havaintokokemus ja sen aiheuttamat tunnevaikutelmat näyttäytyivăt vălineină, joilla pyrittiin vaikuttamaan myös katsojan ajatteluun. Eisensteinin mukaan intellektuaaliset johtopäätökset saavutettiin tehokkaimmin vetoamalla katsojaan emotionaalisesti, herättämällä kuvallisten ärsykkeiden avulla haluttuja tunnevaikutuksia, jotka puolestaan ohjaavat ălylliseen oivaltamiseen. Katsomiskokemuksen kognitiivinen osuus korostui Eisenstein suunnitelmissa 'juonettomasta elokuvasta', joka etenisi ainoastaan emotionaalisten ja kognitiivisten assosiaatioiden varassa. ${ }^{31} 1930$ luvun alussa hän piti intellektuaalisen elokuvan päämäärää toteutuneena:

olemme onnistuneet saavuttamaan taiteemme suurimman tehtãvăn: kuvaamaan abstrakteja ideoita kuvien avulla, tekemăăn ne jossain mãărin konkreettisiksi. Emme ole tehneet sită muuntamalla ideaa jonkinlaiseksi anekdootiksi tai tarinaksi.... On kysymys sellaisen kuvasarjan tuottamisesta, joka herättää affektiivisen liikkeen, joka puolestaan laukaisee ajatusten sarjan. Kuvasta tunteeseen, tunteesta teesiin. ${ }^{12}$

Katsojan kognitiiviset toiminnot eivăt Eisensteinin mukaan juurikaan eronneet emootioista, myös ne olivat perustaltaan refleksiomaisia, fysiologisia prosesseja, joita voitiin săădellă sopivien ärsykkeiden avulla. Kirjoittaessaan eri montaasityyppien vaikutuksista katsojissa Eisenstein pitää karkeimman, "steppavan [metrisen] montaasin" aiheuttamaa motorista imitaatiota identtisenă fysiologisena reaktiona intellektuaalisen montaasin ălyllisten vaikutusten kanssa: 
aikaansaaman edestakaisen huojunnan välillă ei ole mitalăn eroa, silla intellektuaaliset prosessit ovat samaa liikettă, ainoastaan korkeammissa hermokeskuksissa."

Eisensteinin varhainen năkemys psykologisista toiminnoista oli siten hyvin reduktionistinen, katsojan emotionaaliset ja kognitiiviset prosessit ovat palautettavissa fysiologisiksi reaktioiksi. Visuaaliset stimulantit tuottavat automaattisesti, refleksinomaisesti, haluttuja emotionaalisia ja kognitiivisia vaikutuksia. Keskeinen rooli niiden synnyssă ja tehostamisessa on katsojan fyysisillä reaktioilla. Muun muassa nảyttelijän ilmeet ja eleet aiheuttavat katsojassa vastaavia motorisia liikkeitä, jotka puolestaan käynnistävăt ja vakiinnuttavat haluttuja psykologisia prosesseja.

1930-luvun alussa Eisenstein revisioi osittain fysiologista reduktionismiaan ja kiinnitti huomionsa katsojan mentaaliseen prosessointiin. Refleksireaktioiden sijaan keskeiseen asemaan nousi katsojan mieli, joka näyttäytyi kokemusten kartuttamien mentaalisten representaatioiden - ajatusten, tunteiden ja kuvien - varantona. Esimerkiksi 'kello viiden' kăsite on ymmärrettävissă kokemuksen kautta vakiintuneiden assosiaatioiden ryppaaănă. Tăllöin kellon viisarit eivăt ainoastaan kerro aikaa, vaan merkitsevät myös kauppojen sulkemista, vapaa-ajan alkamista, liikenteen tihentymistä jne. Psykologiset toiminnot Eisenstein puolestaan käsitti esimerkiksi Joycen Odysseuksen innoittamana 'sisăisen monologin' kaltaisiksi polveileviksi mekanismeiksi. Edelleen Eisenstein kuitenkin piti tunteita ja kognitiivisia prosesseja keskeisimmăllă sijalla elokuvakokemuksessa. ${ }^{34}$

Münsterbergin tavoin Eisenstein siis hierarkisoi katsojan mentaaliset toiminnot, mutta hăn năki emootiot ainoastaan vălineină elokuvan varsinaisen päămäärän, katsojan rationaalisten prosessien kăynnistămisen ja ideologisen vaikutuksen saavuttamiseksi. Münsterbergin mukaan ideaalinen elokuvakokemus ei edennyt tunteesta teesiin, vaan päin vastoin merkitystä luovista prosesseista emotionaaliseen kokemukseen. Münsterbergin ja Eisensteinin năkemykset elokuvakokemuksen rationaalisesta osasta olivat kuitenkin suurelta osin samankaltaiset, molemmat korostivat assosiatiivisten prosessien merkitystä. Edelleen molemmat tukeutuivat psykologisiin năkemyksiin, jotka korostivat fysiologisten prosessien merkitystä sekä emootioille että kognitiolle.

\section{Kokeellinen psykologia ja klassinen elokuvateoria}

Vaikka Münsterbergin ja Eisensteinin katsoja-analyysien välillä onkin selviä painotuseroja, molempien näkemykset katsojakokemukseen kuuluvista psykologisista prosesseista liittyvät selkeästi samaan psykologiseen tutkimustraditioon, 1800-luvun lopun ja 1900-luvun alun kokeelliseen psykologiaan.

Elokuva oli jo varhain herättänyt kokeellisten psykologien mielenkiinnon lăhinnä katsojan illusorisen havaintokokemuksen - näemme liikkumattomat kuvat liikkeessa - vuoksi. Muun muassa hahmopsykologian varhaisimmassa tutkimuksessa, Max Wertheimerin (1880-1943) 'Experimentelle Studien über das sehen von Bewegung' -artikkelissa (1912) kuvattiin elokuva malliesimerkkină illusorisen liikkeen havainnosta. Nåennăisen liikkeen ilmiötă oli aiemmin selitetty ns. jälkikuvien avulla. Tăllöin oletettiin aikaisempien näköaistimusten sisältyvän osittaisina jälkikuvina uusiin havaintoihin, jolloin liikkeen vaikutelma syntyy 'vanhojen' ja 'uusien' havaintoaistimusten synteesină. Jălkikuvien ja yksittăisten aistimusten sijaan Wertheimer esitti ih-
34. Bordwell 1993, 173, 177.

35. Max Wertheimer, "Experimentelle Studien über das sehen von Bewegung". Zeitschrift für Physiologie und Psychologie der Sinnenorgane, 61, 1912, erit. s.163-186, 221-226. 
36. Münsterberg 1970. 28-30. Tàmă ei kuitenkaan mielestäni riitä luokittelemaan Münsterbergia hahmopsykologian edustajaksi, ks. lähemmin Nyyssönen 1997. Kokeellisen psykologian muista varhaisista selitysmalleista illusorisen liikkeen ongelmaan seka psykologisesta lähestymistavasta elokuvaan ks. myös $\mathrm{H}$ Lehmann, Die Kinematographie, ihre Grundlogen und ihre Anwendungen. Leipzig: Teubner 1911 , erit. s. 1-43.

37. Yleisesityksenä ks. esim. Kurt Danziger. "History of Introspection reconsidered". Journal of the History of the Behavioral Sciences, 16, 1980.

38. Hugo Münsterberg. Die Willenshandlung. Freiburg i. B. J.C.B. Mohr 1888, 55.

39. Ibid., 62 misen muodostavan havaintokokonaisuuksia, joihin tietyissă olosuhteissa toisiaan tarpeeksi nopeasti seuraavat havaintoärsykkeet - kuuluu myös illusorinen havainto liikkeestä. ${ }^{35}$ Münsterberg sovelsi Wertheimerin tutkimuksia tuoreeltaan selittăessăăn katsojan havaitsemaa illusorista liikettă elokuvassa. ${ }^{36}$

Wertheimer esitti selityksensä tueksi sarjan suorittamiaan empiirisiä kokeita ja varhainen hahmopsykologia sijoittuikin vielă selkeästi osaksi 1800-luvun loppupuoliskolla syntyneen kokeellisen psykologian tutkimustraditiota. Sen metodologisena ohjenuorana oli nimenomainen pyrkimys tutkia mentaalisia ilmiöită soveltamalla niihin luonnontieteen empiirisiä menetelmiä - mm. reaktioaikamittauksia, havaintokokeita - ja selittăă ne fysikaalis-kemiallisina prosesseina. Kokeellisen metodin soveltamista rajoittivat kuitenkin filosofiset olettamukset mentaalisten prosessien vălisestä hierarkiasta, esimerkiksi tahdon toiminnan selittämiseen fysikaalisten lainalaisuuksien avulla suhtauduttiin epăillen. Tieteenalan keskeinen auktoriteetti Wilhelm Wundt (1832-1920) ajoi voimakkaasti năkemystă empiirisen tutkimuksen soveltuvuudesta ainoastaan yksinkertaisimpiin psykologisiin toimintoihin, lähinnă năkö- ja tuntoaistimusten analysointiin. Mittavien tieteellisten debattien saattelemana tutkimusalue kuitenkin laajeni varsin pian myös niin sanottujen korkeampien mentaalisten toimintojen, muistin, tahdon, ajattelun ja tunteiden alueelle. ${ }^{37}$ Muun muassa positivistista suuntausta edustaneen Münsterbergin mukaan kaikki mentaaliset toiminnot voitiin alistaa kokeellisen psykologian tutkimuskohteiksi ja ne olivat ainakin periaatteessa selitettävissä empiirisen tieteen metodein:

Jokainen [mentaalisen koneiston herăttãva] liike on materiaalinen tapahtuma, olkoon se refleksi, vietti tai tahdontoiminto, ja se on selitettävissa luonnontieteen fysikaalis-kemiallisten periaatteiden mukaisesti vălttămăttōmănă tapahtumana. ${ }^{3 *}$

Käsitys mentaalisten toimintojen vălisestă hierarkiasta ja uskomus esimerkiksi tahdon tai tunteiden ainakin osittaiseen vapauteen fyysisistă toiminnoista säilyi kuitenkin pitkăăn filosofisena taustaolettamuksena myös positivististen tutkijoiden parissa. Myös Münsterbergin elokuvateoriassa esille tuleva tunteiden priorisointi lienee selitettävissă hănen uuskantilaisen filosofiansa ilmentymänă. Eisenstein puolestaan asetti kognitiiviset prosessit emootioiden edelle poliittisista syistä, elokuvan tehtävänä oli marxilaisleninistisen agitaation levittäminen ja proletariaatin vallankumouksen idean vaaliminen.

Eisensteinin ja Münsterbergin näkemykset katsojan mentaalisten prosessien luonteesta ovat perustaltaan samankaltaiset. Molemmat edustavat varsin pitkälle menevää materialistista reduktiota, jonka mukaan myös emotionaaliset ja kogniiviset toiminnot ovat käsitettävissä kokonaisuudessaan fysikaaliskemiallisina prosesseina, Münsterbergin mukaan jopa vapaalta tuntuva "tahto on vain [fysiologisten] aistimusten yhdistelmă" ${ }^{39}$ Eisensteinin "kostruktivistinen' năkemys on kuitenkin huomattavasti Münsterbergiă yksioikoisempi. 1920-luvun neuvostopsykologian, lăhinnä Pavlovin ja Vladimir Bekhterevin (1857-1927) tutkimuksien, vaikutuksesta Eisenstein olettaa visuaalisen ärsykkeiden synnyttăvăn refleksinomaisesti emotionaalisia ja kognitiivisia vaikutuksia katsojassa. Myös assosiatiiviset prosessit ovat hänen mukaansa refleksien kaltaisia automaattisia toimintoja. 
Münsterberg korostaa psykologisissa tutkimuksissaan myös assosiaation merkitystă, mutta pităă samalla harjaantuneisuutta ja kognitiivisen koneistomme yleistä valmiustilaa merkittävănä lopullisen kognitiivisen ja emotionaalisen vaikutelman syntymiselle. Samalla ärsykeellä on periaatteessa lukemattomia mahdollisuuksia edetă hermostollisia reittejă pitkin ja aiheuttaa vastaavasti myös erilaisia aistimuksia ja mielteită. ${ }^{40}$ Lisăksi assosiaatioprosessit eivăt ole Münsterbergille ja saksalaiselle kokeellisen psykologian traditiolle ainoastaan puhtaita årsyke-reaktio -mallin mukaisia refleksitoimintoja. Assosiaatio ja muut mentaaliset toiminnot operoivat refleksien sijaan aistimusten, tunteiden ja mielteiden muodostamilla mentaalisilla representaatioilla (Bewußtseinsinhalte). Tăllöin emotionaalisten ja kognitiivisten prosessien kăyttövoimana ovat biologisesti ja kulttuurisesti sisäistetyt merkitykset ja toimintamallit, joiden toiminta on moninaisten fysiologisten ja psykologisten lakien sääntelemiă. Eisensteinin refleksikăsityksen muuntuminen mentaalista prosessointia painottavaksi saattaa kuitenkin myös hänet lăhemmäs Münsterbergin psykologista ajattelua.

Münsterberg ja Eisensteinin pitivät katsojan fyysisen reagoinnin merkitystä keskeisenä elokuvakokemuksen muodostumiselle. Visuaaliset aistimukset herăttävät fyysisiä tuntemuksia, motorisia reaktioita, jotka puolestaan antavat vaikutelmansa varsinaiseen mentaaliseen kokemukseen. Molemmat pitivăt katsojan fyysistä kokemusta vălttămăttőmänă sekä kognitiivisten ettă emotionaalisten vaikutusten syntymiselle. Fyysisten reaktioiden merkitys mentaalisten toimintojen muotoutumiselle oli ollut kokeellisten psykologien tiedossa jo pitkăän ja Münsterberg itse oli keskeisessä asemassa motoristen reaktioiden teorian ulottamisessa myös korkeampiin mentaalisiin toimintoihin. ${ }^{41}$ Tunteiden osalta Eisensteinin ja Münsterbergin năkemykset ovat hyvin likeiset niin sanotun James-Langen tunneteorian kanssa, jonka mukaan fysiologiset prosessit edeltävät tai ainakin ovat vălttămăttömiă emootioillemme. William Jamesin (1842-1910) kuuluisa kiteytys esittăă teorian karrikoituna seuraavasti:

Maalaisjărki ajattelee, ettă menetămme omaisuutemme, olemme pahoillamme ja itkemme. kohtaamme karhun, olemme peloissamme ja pakenemme...hypoteesimme mukaan... mentaaliset tilat eivăt seuraa toisiaan valittōmăsti, vaan niiden vălissã on oltava ruumiillisia ilmenemismuotoja...jărkevămpi năkemys on, ettă tunnemme surua koska itkemme. olemme peloissamme koska vapisemme. ${ }^{42}$

Jamesin jyrkkää muotoilua on tulkittu yleensă varsin kirjaimellisesti tunteet ovat vain fysiologisia muutoksia. Lähinnä sillä kuitenkin havainnollistetaan näkemystä, jonka mukaan ruumiilliset reaktiot ovat ainakin jossain määrin vălttămăttömiä tunteiden kokemiselle. Münsterbergille katsojan fyysinen reagointi elokuvassa on ennen kaikkea seurausta samastumisesta näyttelijöihin, jolloin katsoja kokee myös esitettyihin tunteisiin liittyvät fyysiset ilmenemismuodot. Esimerkiksi havaittu kipu saa myös katsojan lihaksiston jănnittymäăn ja samalla kokemaan tunteen todellisena. Eisenstein puolestaan painottaa năyttelijăn eleiden "luonnollisuutta": yksinkertaistetut liikkeet herăttävăt hănen mukaansa parhaiten katsojan motorisen imitaation. ${ }^{43}$
40. Hugo Mũnsterberg. Grundzüge der Psychologie, Leipzig: J.A. Barth 1900, 545-549.

4I. Fyysisten reaktioiden merkitystä psykologisille toiminnoille korostavien motoristen teorioiden historiasta ks. Eckart Scheerer, "Motor Theories of Cognitive Structure. A Historical Review". Teoksessa Prinz ja Sanders (eds.). Cognition and Motor Processes. BerlinHeidelberg: SpringerVerlag 1984, 77-95.

42. William James, The Principles of Psychology. London: Britannia Encycopaedia Inc 1952. 743.

43. Münsterberg 1970, 53: Eisenstein,"The Montage of Film Attractions" (1924). Teoksessa Eisenstein 1988, 48-50.

\section{Kokeellisesta ja kognitiopsykologiasta elokuvatutkimuksessa}


44. David Bordwell, "A Case for Cognitivism" [online]. IRIS, 5:9 1989. Saatavilla muwmuodossa: <http:J/ unw.mailbase.ac.uk/ lists/film-philosophy/ files/ paper.bordwell.htm|>,

45. Carroll 1996, 62-3. Esimerkkinä kognitiotieteen sovellutamisesta antropologiaan ja kielitieteeseen ks. George Lakoff, Women, Fire and Dangerous Things. What Categories Reveal about the Mind, University of Chicago Press 1990 (1987).

46. Münsterberg 1970 , 17.

\section{Michael W.} Eysenck, Handbook of Cognitive Psychology. London-Hillsdale: Lawrence Earlbaum Associates 1988: 45-7. Representaatiot ovat varsin kiistelty alue kognitiotieteen piirissā, kysymys on mm. siitä, tarvitaanko havaintoon korkeampia kognitivisia prosesseja (Marr: mentaaliset representaatiot) vai ei (b.j Gibson: suora, eisymbolinen

havaitseminen).

Debatin implikaatioista elokuvatutkimukseen ks. Hochberg \& Brooks, "Movies in Mind's Eye" (mentaalisten rakenteiden oletus) ja Anderson \& Anderson, "The Case for an Ecological Metatheory" (gibsonilanen näkemys). Molemmat teoksessa Bordwell \& Carroll (eds.) 1996.
Lopuksi on syytä hahmottaa lyhyesti kokeelliseen psykologiaan perustuvien elokuvateoreetikkojen suhdetta nykyisiin kognitiopsykologisiin näkemyksiin elokuvakokemuksesta.

Modernit elokuvatutkijat ovat varsin yksimielisesti nimenneet kognitiopsykologiaksi kaiken psykologian, joka jollakin tavalla koskettaa rationaalisina pitămiămme psykologisia prosesseja. Esimerkiksi Bordwell măărittelee kognitiivisen tutkimuksen seuraavasti:

Yleisesti ottaen kognitiivinen teoria pyrkii ymmărtămatän tunnistamisen, ymmärtămisen, paatơossenteon, tulkinnan, arvostelmien, muistin ja kuvittelun kaltaisia mentaalisia toimintoja. Tămăn viitekehyksen sisăllă olevat tutkijat esittăvăt teorioita siita kuinka kyseiset prosessit toimivat. Edelleen he analysoivat ja testaavat teorioita tieteellisen ja filosofisen tutkimuksen kaanoneiden mukaisesti. ${ }^{44}$

On kuitenkin huomattava, että kognitiopsykologia itsessăăn sisăltäă hyvin erilaisia teoreettisia ja empiirisiă lăhestymistapoja ja ennen kaikkea kăsityksiä mentaalisten prosessien luonteesta. Kognitivistinen elokuvatutkimus nojaa paitsi varsinaiseen kognitiopsykologiaan myös sen sovellutuksiin mm. antropologian, kielitieteen ja keinoălytutkimuksen parissa. Metodologista pluralismia onkin pidetty kognitiivisen elokuvateorian vahvuutena. ${ }^{45}$

Metodologisesta kirjosta huolimatta kognitiopsykologia on kuitenkin elokuvatutkimuksen piirissä ymmärretty pitkăăn varsin kapea-alaisesti ainoastaan perinteisesti rationaalisina pidettyjen toimintojen tutkimuksena. Münsterberg ja Eisenstein pitivăt elokuvakokemuksen olennaisina osina perustavien havaintojen ja kognitiivisten prosessien lisăksi myös emotionaalisia vaikutuksia. Kognitivistit puolestaan ovat pitkăan painottaneet lähinnă katsojan kognitiivisia prosesseja, mistă johtuen sovellutukset elokuvatutkimuksen piirissă ovat keskittyneet lähinnä narratologiseen analyysiin. Rajaus tulee esille jo Bordwellin mäăritelmässä, jossa emootioita ei lueta kognitiivisen tutkimuksen alaan kuuluviksi.

Rationaalisen katsojan ja empiirisen tutkimuksen painottaminen on ilmeinen vastareaktio psykosemioottiselle tutkimusperinteelle, joka karttoi empiriaa ja korosti irrationaalisten ja tiedostamattomien prosessien tärkeyttă. Kognitivistien näkökulmasta keskeiset havaintoon ja merkityksen muodostamiseen liittyvät prosessit nähdään funktionaalisina toimintoina, jotka ovat joko kulttuurisesti tai biologisesti determinoituneita ja struktuureiltaan suhteellisen vakiintuneita. Elokuvakokemuksen kognitiivinen osuus on siten ainakin osittain kuvattavissa ja selitettävissă. Juuri tăssă suhteessa modernilla projektilla on năhty yhtenevăisyyksiä Münsterbergin vuosisadan alkupuolella esittämään haasteeseen, joka asetti elokuvatutkimuksen perustavaksi tehtăvăksi selvittăă "Mită psykologisia tekijöită on osallisena kun seuraamme valkokankaan tapahtumia?"46. Münsterberg luki kyseisiin 'psykologisiin tekijöihin' myös ns. korkeammat mentaaliset toiminnot ja oletti ne perustaltaan rationaalisiksi, fysikaalis-kemiallisten lainalaisuuksien ohjaamiksi ja siten tieteellisten tutkimusmenetelmien ulottuvilla oleviksi.

Myös Münsterbergin ja 'organistisen' Eisensteinin edellyttämät mentaaliset representaatiot tai mentaaliset rakenteet ovat edelleen keskeisiä havaintopsykologiassa ja tiedonprosessointia kuvaavissa malleissa. Esimerkiksi David Marrin niin sanottu komputationaalinen näkemys havainnosta korostaa eriasteisten representaatioiden merkitystă kohteen tunnistamisessa. ${ }^{47}$ Mentaalisten representaatioiden olettamus on myös keskeisessă asemassa kogni- 
tiopsykologiaa hyődyntăvăssä elokuvatutkimuksessa:

kognitivistinen lăhestymistapa, huolimatta taipumuksistaan naturalistiseen selittămiseen, pyrkii nykyisen elokuvateorian tavoin konstruktivistisiin selityksiin sosiaalisen toiminnan kontekstissa operoivien mentaalisten representaatioiden avulla. ${ }^{4 \times}$

Münsterberg korosti kokeellisessa psykologiassaan myös biologisen valikoinnin ja periytymisen merkitystä mentaalisten prosessien toiminnalle:

koko maailma, mukaan lukien ihmiskunta, on yksittäiselle organismille loputon ärsykkeiden lăhde. Ne aiheuttavat hănessă senso-motorisen mekanismin vălityksellă vălttămăttōmãsti sellaisia liikkeita, jotka ovat tarkoituksenmukaisia organismin tai sen jalkelaisten hyvinvoinnille. Juuri năistă liikkeistă koostuvat eläinten ja ihmisten refleksi-, vaisto- ja tahdonalaiset toiminnot. ${ }^{49}$

Psykologiset toimintamallit ja mentaaliset representatiot muodostuvat siten suurelta osin biologisen määräytymisen tuloksena. Münsterberg tosin lievensi äărimmăistä biologista reduktionismia psykologisen teoriaansa kehittymisen myötă. Vastaavalla tavalla kognitiopsykologian piirissä esiintyvillä mentaalisilla skeemoilla (schemata, mental sets, cultural models) tarkoitetaan biologisesti ja kulttuurisesti opittuja toiminta- ja reaktiomalleja, joita yksilő kăyttăă prosessoidessaan vastaanottamiaan ărsykkeitä. Esimerkiksi tervehtimisen kaltaisten sosiaalisten käytänteiden tuntemus ja harjoittaminen perustuu kognitiopsykologisen käsityksen mukaan kulttuurisesti opituille skeemoille. Elokuvateorian parissa $\mathrm{mm}$. audiovisuaalisen kerronnan hahmottamista on tutkittu opittujen prototyyppisten ja skemaattisten mallien avulla. ${ }^{50}$ Lisäksi myös Gibson perustelee 'suoran havainnon' teoriansa biologisilla argumenteilla: havaintokoneistomme on evoluution myötă kehittynyt (tai oikeammin sen on ollut pakko kehittyä) havaitsemaan kohteensa nopeasti, ilman aikaa vieväă mentaalista prosessointia. ${ }^{51}$ Kognitivistisen elokuvatutkimuksen perustaksi biologistista käsitystă kognitiivisista toiminnoistamme on tarjonnut $\mathrm{mm}$. Carl Plantinga:

Koska suuri osa inhimillisestả toiminnasta on eloonjäămisen ja ympäristoön adaptoitumisen motivoimaa, ei ole yllattăvăa, ettă katsoja-aktiviteetin elementit liittyvăt ihmisen adaptiivisiin taitoihin. Ympäristōn ja sen asujaimiston tutkimiseen, ymmärtămiseen ja interaktioon vaadittavien kognitiivisten taitojen harjoittaminen tuottaa meille tyydytysta..s?

Sekä Münsterbergin ettă Eisensteinin analyyseistă kăy esille näkemys katsomiskokemuksesta hierarkkisena prosessina. Molempien lăhtökohtana olivat (luonnollisesti) perustavat näköhavainnot elokuvasta, joista katsomiskokemus etenee emotionaalisiin ja kognitiivisiin prosesseihin. Münsterbergillä kokemuksen hierarkkinen eteneminen materiaaliselta perustasolta (low level) kohti yhä moniselitteisempiă merkitysulottuvuuksia, vaativampia psykologisia prosesseja (high level), tulee hyvin systemattisesti esille. Tendenssi on havaittavissa jopa keskimmäisellä tasolla, ensiksi huomiokykyä kăsittelevässä osuudessa käsitellăăn elokuvalliseen tilaan liittyviă kysymyksiä, jonka jälkeen vasta muistin toimintojen yhteydessä tarkastellaan problemaattisempaa ajan hahmottamista elokuvassa.

Vastaavan kaltainen 'alhaalta-ylös' (down-top) etenevä tarkastelutapa on tuttu myös koginitiopsykologian ja kognitivistisen elokuvateorian parista.
48. Bordwell, "A Case for Cognitivism".

49. Münsterberg 1888 , 52.

50. David Bordwell, Narration in the Fiction Film, London: Routledge 1993 (1985). Vrt. myös filosofinen näkemys empiiriseen

kokemukseen ja skeemoihin perustuvasta epistemologiasta teoksessa Mark Johnson, The Body in the Mind. The Bodily Basis of Meaning. Imogination, and Reason. Chicago and London: Chicago University Press 1987.

51. Katso tarkemmin Eysenck 1988, 28-9 ja Anderson \& Anderson 1996.

52. Carl Plantinga, "Movie Pleasures and the Spectator's Experience: Toward a Cognitive Approach" [oneline]. Saatavilla unw-muodossa: <http:/ /unww.hanover.edu/ philos/film/vol_02/ planting.htm $>$.

53. Eysenck 1988, 3. 
54. Bordwell 1993.

31. 'Tiedostamaton päätelmä' on peräisin saksalaisen

fysiologilta, Hermann von Helmholtzilta. joka kāytti 'tiedostamattomasta" ilmaisua 'unbewußt'. Bordwell lienee tietoisesti välttänyt yleisemmin käytettyä 'unconscious' kāännöstä.

Konstruointinäkemyksensã myötä Bordwell näytcaiisi asettuvan Marrin mentaalisia representaatiota painottavan havaintoteorian kannalle. Kursivointi Bordwellin.

55. Bordwell 1993. 30-3 sekä Bodwellin luento 'Historiallinen poetiiikka' Helsingissā 1.-2.10.1994.

\section{Branigan,} Norrative Comprehension and Film. London-New York: Routledge 1992, 37 . 9.
Kognitiotieteessä erotetaan yleensă toisistaan ärsykeohjatut (down-top) ja käsiteohjatut, 'ylhăăltă-alas' (top-down) etenevăt mentaaliset prosessit. Edellisessă prosessointiin vaikuttavat lähinnă vastaanotetut ärsykkeet (esim. visuaalinen informaatio) kun taas jälkimmäisessä măărăăvănă tekijănă on yksilön subjektiivinen panos (esim. odotukset, muistot). Yleisesti varsinaisen kognitiivisen toiminnan oletetaan sisältăvăn molempia prosessointimalleja. Havainnon sen sijaan oletetaan toimivan lăhinnă down-top -prosessointina, ainakin mikăli visuaalinen informaatio on riittävăn selkeăa.. ${ }^{53}$

Vastaavan năkőkulman elokuvatutkimukseen on siirtänyt David Bordwell. Hănen mukaansa alhaalta ylös tapahtuvat mentaaliset prosessit ovat suurelta osin automaattisia psykologisia toimintoja, jotka liittyvăt havaitsemiseen, esimerkiksi tilan, siinä olevien objektien, värin ja liikkeen hahmottamiseen. Bordwell kuitenkin pităă pelkkăă aistiärsykettă riittämăttömänä selittămăăn havaintoamme, "organismi konstruoi havainnon tiedostamattomien päätelmien [nonconscious inferences] avulla". Esimerkiksi tuttujen kasvojen tunnistaminen vaatii muistin ja odotusten kaltaisten top-down prosessien huomioimista. $^{54}$ Münsterberg puolestaan toteaa samankaltaisesti syvyyden elokuvassa olevan "katsojan lisäämää" ja illusorisen liikkeen havainnon syntyvän "korkeamman mentaalisen toiminnon" tuloksena. Toisin sanoen myős Münsterbergillă havaintoon năyttăă sisăltyvăn ainakin jonkin asteisia high-level/top-down kognitiivisia prosesseja, molemmat kuitenkin pităvăt perushavaintoa suhteellisen automaattisena prosessina.

Havaintoon ja etenkin varsinaisiin havaintoinformaatiota muokkaaviin kognitiivisiin toimintoihin liittyy Bordwellin mukaan myös top-down prosessointia. Tällöin katsoja muokkaa havainnon tarjoamaa informaatiota aikaisemmin omaksumansa (kulttuurisen) tiedon perusteella. Tăhăn lukeutuvat muun muassa aikaisempien taideteosten ja elokuvien perusteella muodostamamme oletukset ja odotukset (skeemat), joiden perusteella teemme hypoteeseja elokuvasta ja siihen mahdollisesti sisăltyvăn tarinan etenemisestă. Top-down -prosessointia Bordwell nimittăä elokuvan haltuunottamiseksi (appropriation). Laaja kulttuurinen konteksti ja automaattisempi, fysiologispsykologiseen rakenteeseen perustuva havaitseminen kohtaavat elokuvan ymmärtämisessä (comprehension). Ymmärtämisen tasolla hyödynnetään erilaisia skeemoja (mm. prototyyppi- ja malli (template) -skeemoja), vakiintuneita tapoja järjestăă havaintoon perustuvaa materiaalia. Skeemat liittyvăt siis lăhinnă varsinaisia kognitiivisia valmiuksia edellyttăville tasoille (haltuunotto ja ymmärtäminen), mutta koska Bordwellin mallissa top-down prosessointi sisältyy jokaiselle tasolle, ne ovat mukana myös havainnossa. ${ }^{55}$

Bordwellin ohella vastaavaa erottelua havaintomateriaalin down-top ja top-down -prosessoinnista ja sen soveltamista elokuvakerronnan analyysiin on käyttänyt myös Edward Branigan. ${ }^{\% 6}$

Samoin kuin Bordwellilla myös Münsterbergillä elokuvan varsinainen merkityksellistäminen tapahtuu hierarkian keskimmăisellä tasolla. Münsterberg ei nimeă huomiokyvyn ja muistin muodostamaa osiota itsenăiseksi alueekseen Bordwellin tapaan, mutta sen funktioiden sukulaisuus on ilmeinen. Bordwellilla ymmărtămisen tasoon liittyy olennaisesti top-down, opittuja skeemoja hyődyntåvä kognitiivinen prosessointi, joka on olennaista elokuvan kerronnan hahmottamiseksi. Myös Münsterbergin 'keskitasolla' analysoimat mentaaliset toiminnot liittyvăt selkeästi elokuvakerronnan ymmärtămiseen. Hăn kuvaa muun muassa huomion ohjaamista kerronnan kannalta merkittäviin tapahtumiin ja kohteisiin (esim. lăhikuvan avulla) sekă kerronnan strukturointia leikkauksen avulla. 
Bordwellista poiketen Münsterberg ei kuitenkaan pidä kerrontaa elokuvan keskeisimpänä asiana katsojan kannalta. Kerronnan sijaan hăn korottaa elokuvan tărkeimmäksi funktioksi emootioiden kuvaamisen ja esittämisen. Kognitivistinen elokuvatutkimus onkin pitkään jättänyt huomioimatta emootioiden osuuden elokuvan katsomisessa ja osana katsojan kokonaisvaltaista elokuvallista elămystă. Muun muassa Bordwell on Narration -teoksessaan emootioiden suhteen varsin niukkasanainen. ${ }^{57}$ Ainoastaan Noël Carroll on kăsitellyt laajemmin (kauhun)tunnetta kognitiivisesta năkökulmasta kirjassaan Philosophy of Horror. Viime vuosina ilmestyneet tutkimukset ovat kuitenkin korjanneet tilannetta myös tältä osin, ${ }^{58}$ tunne ja rationaaliset, kognitiiviset psykologiset toiminnot eivät näyttåydy toisiaan poissulkevina kuten yleensă on ajateltu. Pikeminkin tunteita voidaan ajatella kognitiivisen koneistomme 'hienosăätöjärjestelmănă', ne ohjaavat ja fokusoivat selkeăn rationaalista ajatteluamme. ${ }^{59}$

Münsterberg erottaa katsojassa kahdenlaisia tunteita. Päăosa heijastuu katsojaan elokuvan tapahtumista ja henkilöistă, mutta on olemassa myös tunteita, joilla katsoja reagoi valkokankaan tapahtumiin henkilökohtaisen tunne-elämänsä ja kokemustaustansa perustella. Katsoja siis toisaalta identifioituu năkemäănsă, mutta toisaalta tuottaa myös oman emotionaalisen lisänsä näkemäänsä. Edelleen Mŭnsterberg korostaa sekä psykologisessa ajattelussaan että elokuvateoriassaan ruumiillisten reaktioiden merkitystă emootioiden muodostumiselle. Hăn kannustaa elokuvantekijöitä kirvoittamaan katsojien tunteita esim. leikkausrytmin ja kameratyöskentelyn avulla, joilla voidaan välittömän havaitsemisen kautta vaikuttaa suoraan emootioiden muodostumiseen. Vastaavilla keinoilla voidaan vedota myös katsojien oman psykohistorian pohjalta nouseviin emotionaalisiin vastineisiin. Emootioissa kohtaavat siten automaattiset, fysiologiset down-top- sekä top-down mekanismeilla operoivat kognitiiviset prosessit.

Kognitiopsykologiaan pohjaava elokuvatutkimus painottaa myös ruumiillisten reaktioiden merkitystä emootioiden muodostumiselle. Toimintaelokuvat ovat täynnä Münsterbergin toivomia elokuvallisia efektejă, joilla vaikutetaan suoraan emotionaaliseen kokemukseemme. Fyysis-emotionaalinen reagointi on koettu merkittăvăksi, koska se on yksi mahdollisuus, jonka avulla voidaan kyseenalaistaa katsojan identifioituminen kerronnan osoittamiin samastuskohteisiin. Automaattiset down-top -prosessit tapahtuvat itsenäisesti riippumatta esimerkiksi aikaisemmasta identifioitumisestamme elokuvan păăhenkilöön:

Ruumiillinen kokemus on reaktio elokuvan formaaleille kvaliteeteille ja tapahtumille, joita se esittaă, riippumatta emotionaalisesta suhteestamme henkiloihin. ${ }^{c a}$

Emootioiden ruumiillisen aspektin korostamisen taustalta voidaan hahmottaa kognitivistisen elokuvatutkimuksen yksi keskeisimmistä päämääristä, psykosemioottista teoriaa hallinneen psykoanalyyttisen identifikaatiokäsityksen kyseenalaistaminen. Psykosemioottisen teorian mukaan katsoja erilaisin keinoin altistetaan identifioitumaan năkemăănsă totaalisesti. Kognitivistit ovat kritisoineet năkemystä muun muassa siitä, ettei se huomioi katsojan omaa aktiviteettia ja siită kumpuavia mahdollisuuksia reagoida eri tavoin näkemăänsă ja samalla myös varioida identifioitumisen asteita. Esimerkiksi Murray Smith näkee identifioitumisessa - oikeammin emotionaalisessa suhtautumisessa elokuvaan (engagement) - erilaisia tasoja (alignment, allegiance), jotka sisăltăvăt myös kognitiivisia prosesseja, kuten pyr-
57. Ks. Bordwell 1993. $39-40$.

58. Katso esim. Carl Plantinga, "Movie Pleasures and the Spectator's Experience", Carl Plantinga, "Affect, Cognition and the Power of the Movies". Post Script vol. 13:1 (Fall 1993) ja Murray Smith, Engoging Characters.

Fiction, Emotion, and the Cinema. Oxford: Clarendon Press 1995.

59. Smith 1995, 62.

60. Plantinga, "Movie Pleasures and the Spectator's Experience" 61. Murray Smith 1995, 6-7.83. 
kimyksiă ymmărtăă elokuvan henkilőită ja heidăn kăyttăytymistăăn (alignment). ${ }^{61}$

Münsterberg ei erota teoriassaan erilaisia identifikaatiotasoja, hănen mukaansa katsoja kokee täysin samat tunteet kuin mitä hănelle valkokankaalta esitetăăn. Merkittävăă kuitenkin on, ettă hän myös näkee vaihtoehdon identifikaatiolle painottaessaan voimakkaasti subjektiivisen panoksen merkitystă elokuvan emotionaalisen merkitystason luomisessa. Edelleen Münsterbergin 'kognitiivisen' lähestymistavan merkittävyyttă osoittaa se, ettă hăn pităă katsojaa harmonisena kokonaisuutena, johon kuuluvat ja jossa yhdessä vaikuttavat niin kognitiiviset kuin emotionaalisetkin prosessit. Münsterbergia voidaan verrata osittain Eisensteiniin, joka myös ymmärsi emootioiden merkityksen katsojalle. Hänen projektinsa on kuitenkin păinvastainen kuin Münsterbergin. Eisensteinin "tunteesta teesiin" etenevă ideaalinen katsomiskokemus năyttăytyi Münsterbergille fysiologisten reaktioiden ja kognitiivisen merkityksemuodostamisen kautta elokuvan emotionaalisena ymmărtămiseenă ja myötăelămisenă. 